\title{
FLOW NOISE
}

$\mathrm{D}^{\mathrm{c}}$ URING the latter part of the last century, the great scientists who studied acoustics attacked and solved most of the problems of acoustic excitation and propagation, the one notable exception being that of sound created by moving air. Since that time, partly because of its relative unimportance, but chiefly because of its intractability, the acoustician has only tackled the problem in a physical manner to explain the discrete frequencies which occur when air blows over wires (aeolian tones) or on to a sharp edge (edge tones) and has not at any time appealed to mathematics to obtain quantitative solutions. Since the Second World War, the greatly increased power used in civil airliners, made possible by the invention of the jet engine, has brought forth a noise situation in which the enormous power developed has more than outweighed the inefficiency of conversion of kinetic energy and has precipitated a major conflict between the flying and non-flying public. A detailed study of jet noise has thus become urgent, and this has brought into the field of acoustics those scientists who have, by tradition, been most knowledgeable about the details of the source, namely, the fluctuating flow in the jet as it mixes with the surrounding air. Since the acoustic output of a typical jet engine consists of only one-hundredth of 1 per cent of the total engine-power, this has involved a highly mathematical treatment. Hence, in Britain, the acoustician with his physical interpretation and the aerodynamicist with his mathematical approach have tended to keep apart, even while dealing with the same problem.

Thus it was that, at the joint meeting of the Acoustics Group of the Physical Society and the North-eastern Branch of the Institute of Physics held in Newcastle upon Tyne during November 15-16 under the joint chairmanship of Prof. E. G. Richardson and Dr. O.P.T. Kantorowicz, the major outcome was the cross-fertilization of ideas arising from these two groups. Indeed, as Prof. E. J. Richards (Southampton) pointed out in his introductory address, noise suppression has now become a study of turbulent mixing and has moved some way from pure acoustics. Thus, whereas the two-day conference was split into sessions on noise in air and in water, respectively, the natural gulf was, in fact, that between papers on turbulence and on discretefrequency sound.

In the first category, considerable interest was aroused by three papers concerned not with noise and its propagation but with the aerodynamics of jet flow. In his talk, Dr. G. M. Lilley (Cranfield) examined the terms of Lighthill's equations and from them put forward valuable ideas regarding the essential parameters on which jet noise is based. He also examined in more detail than in the past the nature of the turbulence of the stream and its significance in contributing to the quadrupole sources of sound. Probably his most interesting proposal concerned a suggestion recently made by Townsend, that eddies emanating from a jet can be likened to long vortices stretching downstream with their axes along the line of the jet. $\mathrm{He}_{\theta}$ speculated that since these supply the major energy-carrying eddies, they are probably the greatest sources of sound; the obvious corollary to this is, of course, that noise- suppression techniques should be based on the deliberate destruction of these toroidal vortices, presumably by cross-flows and quick mixing systems.

In this category of papers on turbulence and its relationship to noise were also two pepers from the United States: Dr. R. H. Kraichnan, of the University of New York, talked about the pressure and sound fields of turbulence with high Reynolds number, while Dr. E. Skudryzk, of Pennsylvania State University, presented some most interesting results regarding the noise produced by the boundarylayer turbulence of a rotating cylinder. Undoubtedly these three papers, involving the relationship between wide-spectrum noise and turbulence, indicate the direction of future flow-noise researches at least for the next five years.

The other papers presented in this two-day conference dealt almost exclusively with discretefrequency sound phenomena. Such phenomena are, of course, much easier to picture physically and were received with considerable interest by the less mathematical members of the conference. Edge tones in water were described by Mr. M. Gross (Newcastle). Dr. J. H. Gerrard (Manchester) described his experiments on the singing of wires (aeolian tones); the hydrodynamic oscillator was described by Dr. G. G. Parfitt (Imperial College of Science and Technology, London) and the effect of nicking on organ flue pipes by Dr. D. M. A. Mercer (Southampton). It is impossible in the space available to describe these interesting contributions, nor the general survey by Mr. M. P. Tulin of the waternoise researches being carried out in the U.S. Naval Research Laboratories, in any detail. Dr. Parfitt's description of the work at Harvard in developing a hydrodynamic oscillator which provides a sound level of 165 decibels in air for the expenditure of only 14 watts in energy shows how noise and pressure resonances, normally a nuisance, can also be harnessed to provide a very efficient means of energytransfer.

As would be expected in the study of sound by aerodynamicists, optical schlieren techniques have become the accepted method of studying discretefrequency phenomena. One of these phenomena. arises from the sound which is given out when an eddy passes through a shock wave. Since this sound

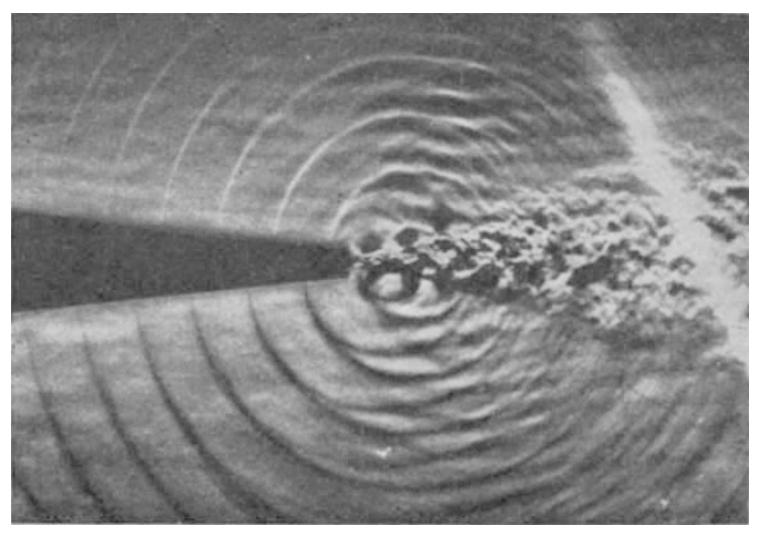

Fig. 1 


\section{No. 4806 February 8,1958}

wave proceeds upstream and produces a fluctuating flow, it is easy to see that for some frequency a selfsustaining system or resonance will occur. Two somewhat similar papers on this subject were presented at the conference, one by Mlle. Merle (Marseilles) and Mr. M. G. Davies (Liverpool). Both authors described their work on the 'back reaction' or resonance mechanism, Mlle. Merle showing a most interesting film of the cellular pattern in the jet. Mr. Davies gave more attention to the geometry of the system and a method of prediction. of the frequency. The standard of photography was excellent in both cases; a typical photograph by Mr. Davies showing the sound waves emanating from the choked jet stream is shown in Fig. 1.

During the conference, members were conducted around the laboratories of the Pametrada Research Station and the cavitation tunnel at King's College, Newcastle. It is to be hoped that this meeting will be only one of a series drawing together workers in acoustics and aerodynamics, separated as they are now by the wide gulf of tradition.

\section{ENZYME CHEMISTRY}

$\mathrm{A}^{\mathrm{N}}$ $\mathrm{N}$ international symposium on enzyme chemistry organized by the Science Council of Japan was held under the auspices of the International Union of Biochemistry in Tokyo and Kyoto during October 15-23. The president of the symposium was Dr. Seiji Kaya, president of the Science Council of Japan, and Dr. Keizo Kodama was chairman of the organizing committee. The meeting was reported to be the largest international gathering of scientists held in Japan since the War, 108 non-Japanese from twenty-one countries and 816 Japanese being present. The attendance from Western European countries was regrettably small, about half the overseas visitors being from North America, eight from the Soviet Union and numbers of from one to four from other countries. The thoughtfulness of the Japanese in presenting their work for the most part in English went a long way towards overcoming the language barrier, and their friendliness and the very great care with which our Japanese hosts had evidently planned every detail of the excellent organization made for an exceptionally smooth-running conference. Both at the University Club at Tokyo and within the University buildings at Kyoto, large and wellequipped reception and meeting rooms were provided. All participants received on arrival a massive volume containing the text of some 150 communications; the printed proceedings are to be published later and will include the discussions which followed the presentation of these papers.

Special lectures were given by Britton Chance on cytochromes in living cells, by $\mathrm{H}$. Tamiya on the koji as a source of enzymes in Japan, by W. A. Engelhardt on enzymology and mechanochemistry, and by F. Lynen on the phosphate cycle and the Pasteur effect. H. Theorell and F. Lipmann, who were to have delivered conference lectures, were, unfortunately, unable to attend.

The proceedings were grouped under four main topics : mechanism of enzymic group transfer; enzyme systems of hydrogen, oxygen and electron transfer; formation of proteins and enzymes; enzymes and industry.

It would be impossible to mention here more than a few of the individual contributions, most of which maintained a high scientific level. The enzymic synthesis of polynucleotides was described in pepers by A. Kornberg and S. Ochoa; lipoic acid and its functions in keto-acid metabolism by L. J. Reed and I. C. Gunsslus; pyridoxal-catalysed enzymic metabolism of amino-acids by E. E. Snell, A. E. Braunstein and $K$. Ichihara and their colleagrues. Japanese work on cytochromes was reported by $\mathrm{K}$. Okunuki,
M. Ishimoto and S. Minakami, among others. A striking feature of the exhibition held in connexion with the symposium was the display of crystalline cytochromes by Japanese workers. In the same exhibition was a surprising range of crystalline proteolytic and other enzymes, of which some were commercially available, large samples being generously presented to visitors. Japanese work of industrial importance on the fermentative production of adrenaline and glutamic acid was presented at the scientific meetings.

Further papers concerned oxidative phosphoryla. tions, to which subject outstanding papers were contributed by D. E. Green, B. Chance, A. L. Lehninger and E. C. Slater; while various other aspects of phosphoryl group transfer were described by A. H. Ennor, H. Tamiya and O. HoffmannOstenhof. Biosynthesis of peptide bonds in relation to cell-structure was described by N. M. Sissakian and by T. Peters, and W. E. Knox gave a valuable account of adaptive enzyme formation in animals. The three members from the United Kingdom ( F. Dickens, M. R. Pollock and C. Rimington) also presented papers.

At the closing session, Prof. A. Akabori, chairman of the Executive Committee, to whom must go much of the credit for a splendid job of organization, summed up the events of the symposium, and Prof. M. Florkin as president of the International Union of Biochemistry eloquently put the appreciation of the Union. The thanks of non-Japanese members were expressed by Prof. A. K. Balls who, on their behalf, presented to Prof. Kodama an illuminated scroll contrining the signatures of the overseas members together with a brief message of appreciation in Japanese, offering their thanks and congratulations on a remarkably valuable and enjoyable symposium.

A full and varied programme of social events was provided, including a number of receptions, displays of Japanese dancing, the tea-ceremony and other picturesque traditional Japanese customs. Many overseas visitors were also able to enjoy the unique experience of life in a ryokan, or Japanese-style hotel, a charming and restful contrast with the bustle and noise of modern Tokyo.

Very attractive glimpeses of the beautiful Japanese countryside were provided by excellent rail and bus excursions to the National Park at Nikko, to the ancient city of Nara and to the extremely interesting pearl-fisheries at Kashikojima.

After the symposium, three short further meetings were held. In Kyoto, Prof. Yas Kuno presided over a first-class two-day conference on water-soluble 